\title{
Departures and returns: cultural identities, historical traumas and personal paths in Susan R. Suleiman's Budapest Diary
}

\author{
Zoltán Z. Varga ${ }^{1,2}$
}

Published online: 6 October 2020

(c) The Author(s) 2020

\begin{abstract}
This paper studies Budapest Diary (1996), a cross-genre autobiographical work by Susan Suleiman, a renowned Hungarian-born scholar in comparative literature. Suleiman's life writing offers particularly interesting reading possibilities; it allows us to study recent theoretical issues from historical traumas to multicultural and multi-linguistic identity constructions. My paper focuses on how Suleiman examines her past as a literary critic and expert on the modern novel, how her theoretical background as a comparatist formed and fashioned her autobiographical project. A close reading of her Budapest Diary reveals not only the generic patterns, the narrative and poetical means borrowed from her literary formation but also theories that enable the author to analyze her past, the social, cultural and historical determinations manifested in her life story. My interpretation devotes special attention to the image of Eastern-Europe developed in Suleiman's autobiographical work. I analyze the way the work of the author, who returned to her homeland as an adult, seeks not only to find the reasons for burying the past burdened with collective historical traumas, but also tries to discover the regional components of identity, of the cultural otherness of East-Central Europe. The paper aims to show how collective and personal stakes are intertwined in the difficult process of reacquiring her Hungarian past in the light of her relationship with her parents (especially with her mother), and that of the history of Jewish people in Eastern Europe during the $20^{\text {th }}$ century.
\end{abstract}

Keywords Susan R. Suleiman · Academic autobiography · Transcultural identity · East-Central Europe · Historical trauma · Jewish identity

Zoltán Z. Varga

varga.zoltan@pte.hu

1 Faculty of Humanities and Social Sciences, University of Pécs, Pécs, Hungary

2 Research Centre for the Humanities, Budapest, Hungary 


\section{Writing inside and outside the academe: academic autobiographies and autobiographical exile writings}

Personal criticism and academic autobiography as intersections of literary criticism and life writing studies have progressively gained legitimacy in academia since 1970. By the turn of the millennium scholars in the humanities had published a wide range of autobiographical accounts varying from artistic (and narcissistic) selfmythologies to humble intellectual-career stories, from histories of political engagements to psychological self-analysis. Yet, by observing the massive autobiographical production in the academia, one might agree with the harsh opinion of the French historian Pierre Nora who, in his introduction to Essais d'ego-histoires (Agulhon and Nora 1987), a collection of French historians' career analysis by themselves, disavowed "phony literary autobiographies, pointless intimate confessions, abstract professions of faith, or attempts at basic psychoanalysis" to oppose them his and his fellow historians' self-reflective "exercise ... to clearly set down one's own story as one would write someone else's" (Nora 2014). Nora himself attributes a limited function to academic life writing which, according to him, should entail methodological self-reflection. Researchers' autobiographies offer an opportunity to study their social origins and determinations, as well as the formation of their intellectual reflexes and way of thinking, so it may result in a raised awareness and control of inherited political convictions and system of social values, which might direct the scholarly research in an unconscious way. Obviously, most academic autobiographers write their memoirs with more personal ambitions than a simply exercise of self-objectivation, and the "life and work" topos supposes a stronger connection between theoretical thoughts and personal background. A true academic autobiography is more than a collection of personal memories; it seeks to shed light on how even the most abstract ideas are rooted in the life stories, personal and sometimes even intimate experiences of their authors.

At first glance, Susan R. Suleiman's Budapest Diary (Suleiman 1999) is rather an autobiography by an intellectual than an intellectual (or academic) autobiography. In this autobiographical book, the Hungarian born comparatist from Harvard reveals some fragments of her childhood years in her native country (among them the hair-raising stories of her survival of the Nazi persecution in 1944-1945, her family's escape from Hungary after the communist takeover in 1949 at the age of nine, and their emigration to the United States), then the stories of two return visits in Budapest, one during the mid-eighties when Hungary was still under Communist rule, the second in 1993 as a fellow of the once prestigious Collegium Budapest. However, the relationship between the story of her own life and her scholarly work remains implicit insofar as her intellectual formation (education, readings, research etc.) is hardly treated in her book, the development of her ideas is not presented in its historical evolution, and the academic field with its institutions and its formative power on research topics of the oeuvre remains in the background. Indeed, Suleiman does not intend to describe the process which transforms life events and personal experiences into theoretical insights, nor does she try to make up a synthetizing narrative about her intellectual maturation. 
Although, the book is not a linear narrative based on casual logic, and does not provide a complete and systematic account of decisive experiences shaping the thoughts of its author, some of those determining moments could be easily spotted in Budapest Diary. Its author-narrator explores her past and present life as a fullfledged scholar, dividing her attention between private issues (childhood memories and her relationship with her parents) on one hand, and collective subjects (comparison of cultural differences between the US and East Europe, the destiny of Hungarian-and Eastern European-Jewry, political problems of new Eastern European democracies etc.) on the other. These implicit connections with Suleiman's scholarly work are already studied by Ioana Luca (2009) who proposes a diacritical approach to Budapest Diary by reading the autobiography proper in the light of Suleiman's preceding and following scholarly works, Risking who one is (Suleiman 1994) and Crisis of Memory (Suleiman 2006). Luca argues that "the writing of her memoir and the re-examination of experiences as a Holocaust survivor, first, and as an Eastern European returning to her native country, second, lead Suleiman to a radical shift in her orientation as a literary critic" (Luca 2009, p. 268). Luca's paper aims to understand how "the implications and consequences of writing a memoir [...] complements and complicates her [Suleiman's] scholarly work" (Luca 2009, p. 268), how the biographical elements find their way into this scholarly work through a thorough analysis of the thematic and methodological changes in the oeuvre of Suleiman. According to Luca, two concepts in Suleiman's theoretical work seem particularly linked to the rediscovery and the exploration of personal past. The notion of autobiographical reading developed in Risking who one is implies a double autobiographical dimension: a particular fascination by a work of art which is often proved to be autobiographical prompts the reader to formulate her/his own existential problems and in turn write her/his own autobiography. Suleiman, captivated reader of Holocaust memoirs, especially those of child survivors, discovers her own repressed wartime experiences as a Hungarian Jewish child survivor of the Nazi persecution thanks to the texts of Perec, Wiesel or Federman among others; then she in turn writes her war in four episodes as the final chapter of the Risking who one is. This short text, composed during her stay at Budapest in 1993, can be considered as an avant-texte to Budapest Diary (indeed, it is included in it) and a first step toward an openly autobiographical writing project in the margins of the academic discourse. But it also has its own function inside Risking who one is too, namely to clarify her emotional motivations and to channel them into her research. According to Luca, Suleiman's testimony about her own traumatic experiences in her autobiography proper contributed to the coining, a few years later in Crisis of Memory (2006), of the notion of the 1.5 generation of Holocaust survivors, another concept in her scholarly work which is closely related to the exploration of her personal experiences. Luca's analysis shows that Suleiman learned from her own story, told in Budapest Diary the dialectic of oblivion and remembering, the slow process of facing the traumatic past which characterize the writing of child survivors of the Holocaust.

Traumatic experiences during World War II are not the only autobiographical elements that seem to have had an impact on Suleiman's thought in the nineties. Budapest Diary is also a book about immigration, assimilation and homecoming, 
about the experiences of a person with a multicultural background. The title, made up of a Hungarian proper noun and an English noun announces the story of an "Eastern European intellectual who returns after the fall of the Iron Curtain to revisit her country and translate the "otherness" of her country to the West" (Luca 2009, p. 268). Experiences with personal and existential dimensions are not necessarily unique, individual experiences. Suleiman's work fits into those stories of homecoming or returning visits which were written by many Eastern European intellectuals after the collapse of Communist regimes in 1989, dedicated to telling the experience of immigration or exile from the perspective of the return to countries of origin, typically from North America. In many cases not only the historical events, the fall of Communist regimes and reunification of Europe, but also private issues incite the autobiographical reflection. As Alfred Hornung claims in an article dealing with stories of homecoming by Eastern European exiles after 1989, "moments of personal crisis, such as the illness and imminent death of parents, coincide with historical moments of change in Eastern Europe after the fall of the Berlin Wall and the collapse of the Communist Block in 1989. Both the private and the public ruptures in life and history become the primary motivation for writing one's life" (Hornung 2013, p. 14). In that respect, Susan R. Suleiman's autobiography is not an exception, as the author conceived the idea of returning to her birthplace after 35 years only when she realized the imminence of her mother's death. Life writings of émigrés confirm the rule of genre insofar as the autobiographical temptation is often connected to one of the classical features of the genre, to the age of the autobiographers, who are supposed to be mature and experienced enough to produce an instructive story for their public. The former émigrés or exiles in their middle years obey to the call to face their own past and that of the communities to which they belong.

The corpus of life writings from Eastern European émigré or exiled intellectuals inspired a keen interest both for researchers of the cultural and political history of the region, and for experts in autobiographical studies. John Neubauer, who in 2009 coedited a comprehensive volume entitled The Exile and Return of Writers from East-Central Europe: A Compendium, noted in its introductory chapter that "studies of writing in exile must go beyond imaginative literature and include autobiographies, correspondence, and other personal writings that are often produced by journalists, philosophers, essayists, historians, and other professionals" (Neubauer 2009 , p. 13). The extension of the scope of sources helps the social historian gain an increased understanding of how a transcultural identity is formed via mediation and negotiation between two languages, two societies, and two systems of values; they show us the process of "the acquisition of a complex, multiple personality and a multi-perspectival view of experience" (Neubauer and Török 2009, p. 398). Specialists of autobiographical writings and social historians of the exiled experiences use memoirs, diaries and other personal writings to analyze the political, social and moral dynamics that constitute a life story and offer a perspective to understand the role of different life representations in this dynamic too, because "autobiographical writings gain special prominence in exile for such preoccupations with the self" (Neubauer and Török 2009, p. 398).

Susan R. Suleiman is not only a contributing author to the volume The Exile and Return of Writers from East-Central Europe (she wrote a chapter about Imre Kertész 
and the question of internal exile). Her Budapest Diary is analyzed in detail by another contributor, Ksenia Polouektova, in a chapter devoted to Autobiographical Exile Writings. Polouektova compares Suleiman's autobiography to a classic piece of Eastern European exile literature and academic autobiography, Eva Hoffman's Lost in Translation (Polouektova 2009). The social and professional paths of the two authors show great similarities, even if the two autobiographical works analyzed in the paper are different in terms of narrative form, because Hoffman's book is a retrospective, synthetizing narrative, while Suleiman's proposes a dialectical form of life writing. Both Hoffman and Suleiman left Eastern Europe in their childhood; their families were pushed to emigrate by the postwar anti-Semitic feelings in their native countries. They both had a successful career as literary scholars in the New World, and chiefly their literary cultivation, the way they connect the question of identity to language and culture, and their reflected and conscious approach to literary forms have considerably influenced their own autobiographical accounts.

Examples like Lost in Translation and Budapest Diary outline the similarity between the experience of the exiled and the situation of the specialist in comparative literature studying works of world literature. The scholar trying to interpret texts, cultural products or social habits as not native, and the exiled person's attempt to decipher intimate dimensions of a culture and society in which she/he is not born in are similar. Both the exile and the comparatist are in the middle of an intercultural and interlinguistic exchange; they are the subjects and the media of a cultural translation, both practice an (inter)cultural hermeneutics. Indeed, Emily Apter (1994) suggests that the exile situation and "... the theoretical topoi of placelessness [is] imbricated in the very essence of what comparative studies is all about" (Apter 1994, p. 93). Nevertheless, the similarity between the two situations is rather hyperbolized because the need of interpretation is more immediate for an exiled person whose survival and fortune depend partly on her or his ability to decode properly social and cultural laws regulating social relationships in his or her new home. For a comparatist, the cultural and linguistic distance separating her/him from the studied object should always be methodologically reflected, and the perspective of the outsider or the stranger can even raise new and inspiring questions concerning the analyzed cultural artefact or product, while for the exile, cultural and linguistic differences often manifest in terms of exclusion, incompetence and cultural inferiority.

Susan R. Suleiman's Budapest Diary also connects her skills as professional comparatist and her personal experiences as an exile, her double tie to Eastern Europe and North America. The book does not pretend to determine Eastern or Western European identity in an essentialist way, even if it presents stereotypes like the depictions of sardonic and melancholic Eastern European intellectuals or pragmatic North American women. Her autobiographic work depicts an image of Eastern-Europe in its modern historical context, with its intellectual reflexes and typical ways of thinking, with its fears fed by local historical experiences. This image of Eastern-Europe, and more precisely, that of Hungary in its twentieth century past is viewed from a double viewpoint, that of the native and the stranger, so the familiarity of the birthplace and the childhood world occurs through cultural and temporal distance. Budapest Diary focuses on collective identity patterns, it reflects on identity-constructions determined by local history and culture; and it does so by 
relating personal stories, by revealing private and even intimate dimensions of its author's life. It seeks to understand the cultural and historical inheritance manifested in personal experiences. In other words, Suleiman practices cultural hermeneutics: she tries to understand her "in-between" identity and, at the same time, the cultural/ political/historical multiplicity from which this identity is constructed. But the two poles of this exchange or dialectic are not equal: the Eastern Europeanness as cultural-historical entity is subordinated in her work. As I will develop later, in Budapest Diary Hungarian history, social life and "people" are observed from a position which often reproduces the opposition of the "civilized observer" and the "savage native."

Beyond this double cultural and intellectual determination of her identity construction and writing position, Suleiman's autobiography has a clear political dimension. She attributes a manifest political meaning to her departure from her birthplace, although the interpretation of the emigration is a result of a retrospective construction. Suleiman ascribes particular importance to her rupture with her community of origin, and she partly identifies Hungary with the totalitarian political regimes (first Nazi in 1944, then Communist in 1948) which expelled her and her parents from their home, deprived them of belonging to the Hungarian nation as an imaginary community. This rupture, and the exile ensuing from it, is probably at the heart of the formation of a political subject, whose development is represented in an indirect way in Suleiman's work; its theorization played a considerable role in the formation of a self-conscious, autonomous personality with a sharp critical attitude toward forms of (political) repression. Different types of political repression bred different types of political commitment. Suleiman who survived Nazi persecutions in Hungary with her parents during World War II as a Jewish girl, remains sensitive to antisemitism in its historical and contemporary manifestations.

In Budapest Diary, theoretical discourse, personal narratives, confessional postures, analysis of the historical, political and cultural contexts meet in a central topic: the theme of home. Home is usually understood in the singular, as a synonym of origin, of identity, of security, of familiarity and of family. None of these concepts are obvious for Suleiman. In what follows I will examine how her life writing tries to extend the meaning of homes in the plural, by reconciling with her past both in the collective dimension as an exiled Jewish Hungarian returning to her birthplace, and in the personal dimension, by an intimate but at the same time transcultural dialog with an absent other, with a mother who passed away without sharing stories about her past.

\section{"It was as if my past had never existed": generic patterns, temporal condensation, narrative structures in Susan R. Suleiman's Budapest Diary}

Suleiman's work can be classified as a hybrid autobiographical genre. On the one hand, it belongs to the tradition of classical autobiography writing: it relates a series of crucial events having an impact on the development of one's personality, it sketches familial and social contexts, it reveals intimacies evoking the situation of a 
confession. But on the other hand, the intellectual reflection on her autobiographical enterprise becomes more important than it usually is, and importantly, its function is utterly different from that of the general philosophical and anthropological analysis on subjectivity present already in the early masterpieces of autobiography, such as in the Essays of Montaigne or in the Confessions of Rousseau. While these classical pieces of autobiography postulate a universal subject of "mankind" manifested in an individual life story, the subjects of autobiographies such as Budapest Diary can only be apprehended through their cultural and historical specificities. Autobiographers with transnational and transcultural backgrounds practice "autoethnography;" they focus on how disparate cultural elements and social contexts in given historical moments determine a life. Furthermore, they give voice to cultural and political criticism in personal narratives and in memoirs; being "situated at the intersection of intimate self-portraiture, linguistic travels and travails, and a poetically nuanced triangulation of dislocation, memory, and human agency," they "offer a diversity of strategies for writing about loss and critical insights into the vicissitudes of personal and communal remembrance" (Seyhan 2012, p. 70).

Budapest Diary is not a diary. Although the generic denomination "diary" occurs in the title of the book, it does not describe the genre of the book properly. Indeed, the text is composed of four parts, which present in chronological order some episodes of Suleiman's life, each of them connected to Hungary and to her parents. Among these autobiographical "chapters" only one, actually the longest, respects the form of diary - kept during a six-month academic visit to Budapest in 1993the others are retrospective narratives. Nevertheless, the paratexual elements (prologue, photos of the family and their first home), ${ }^{1}$ as well as the doubtless identity of the author, the narrator and the protagonist referred to with a well-known proper name for an academic readership confirm the autobiographical pact: no matter if the book is classed as diary or autobiography, the well-informed public reads it as a work in which a real person tries to tell something important about her own life.

The first part, entitled "Prologue: Forgetting Budapest," tells retrospectively the detailed story of her family's escape from Hungary in late summer of 1949. As mentioned before, this introductory part of Budapest Diary, written in retrospective prose, was already published in 1994 as the final essay of the Risking who one is, under the title of "My War in Four Episodes" (Suleiman 1994, pp. 215-243). The narration is linked here to the perspective of the author, a ten-year-old girl, and the story is followed by some general remarks on the genesis and the principal goals of the book from the point of view of the grown-up writer. This dramatic, adventure story-like, in medias res beginning suggests a conscious narrative construction, grasping the reader's attention at the outset of the text. At the same time, the novelistic, "literary" ambition is controlled by a self-aware intellectual analysis of this late rediscovery of her own past, as well as that of her family and her native country. The second part, "1984: A Brief Vacation," tells in retrospective narrative the story of a

\footnotetext{
1 A familial photo representing the author as a young girl with her mother and her father, as well as the picture of their former flat in Budapest taken from the courtyard were added to the e-book edition of Budapest Diary.
} 
two-week stay when the author returned to Budapest for the first time after thirtyfive years. The story of the first return is not only a travelogue, but contains many childhood memories (among them the story of her family's hiding from the Nazis during the last months of the war), stirred up by the evocative power of revisited venues of past events. The third and longest part, which lends its title to the book, is effectively written in real diary form. Its day-by-day perspective focuses rather on the time of its writing, and the diarist notes interesting events and meetings that happened during the six months of her professional stay at the Collegium Budapest in 1994, commenting on political news in Hungary at the time. However, respecting the most important rules of diary-writing does not prevent her from crafting its realistic material by dividing her text into four suggestively titled sub-sections, as if she wanted to form chapters in a fictional narrative: the subtitles- "Through a Stranger's Eyes", "The Center of Europe", "Quiet days on the Danube", and "Enormous Changes at the Last Minute"-summarize the main topics of the daily notes from a retrospective vantage point and lay out the narrative material in order to excite the readers' expectations. The last section ("1994: Acacia Street") tells about another short trip to Budapest in 1994, which can be considered as an epilogue, a final attempt to complete the author's fragmented familial history.

Admittedly, the disposition of the four parts respects chronological order, but the temporal structure of whole work is made more complex by the insertion of retrospective narratives of childhood memories. In Budapest Diary the time of remembering (the present time of the visits in Budapest, but also that of the writing) and the remembered time (the time of childhood and youth) are intertwined, therefore the book is as much the story of remembering as the finally recollected story of the familial past. Memories occur gradually, as often happens in confessional genres dealing with traumas: the fragmented appearance of the past events in the narration expresses the difficulties of remembering. The book seeks to answer the question why her childhood is cut off from the life story of the author, and how to reintegrate it to her narrative identity. Here, we may identify a third narrative instance in the process of writing, which could be described not only by its temporal position (the little girl in the past or the adult traveler), but rather by an external, reflective instance, responsible also for the dramatization of the story:

it was as if a door had shut behind me when I left, sealing the first ten years of my life in the air tight room. For thirty-five years I had managed not to give much thought to the room. What would happen now, if I turned the knob on the door (Suleiman 1999, p. 20)

It is obvious that the knob on the door is already turned, and this last rhetorical question belongs to the logic of presentation, it is a part of a narrative trick which underscores the emotional tension of facing the repressed personal, familial and collective past: the repressed image of the migrant behind the assimilated and established American citizen ("the professor at Harvard"); the repressed image of a little girl trying to find her place in the complicated relationship of her parents; the repressed image of a persecuted Jewish family, forced into exile from their Eastern European home. These three narrative instances are confronted and analyzed throughout the work, and they are interconnected in the theme of identity. 
The concept of narrative identity relies on the idea that every one of us has a tacit life story of herself or himself, which could answer the question "Who am I?" But these stories are rarely written or told spontaneously; their authors are most often pushed by some extraordinary events, generally connected to a(n identity) crisis to tell or rather re-tell the story of their life. Suleiman's Budapest Diary is no exception, because her inquiry into her own past and her ancestors' life in Hungary was triggered by the imminent death of her mother, but also by a critical age when selfevident pursuit of goals and desires of youth seem exhausted, when maybe for the first time in the adult life an inventory of things achieved and deeds done has to be made.

I decided before the end of my mother's visit that I had to take my children to the place where I had known this young woman. [...] I decided to see again, and let my sons to see, the city of my childhood, which had suddenly become for me, now that she was dying, the city of my mother's youth. (Suleiman 1999, p. 11)

The recognition of the elements of her mother's life story in her own life plays an important role in the work, as the subtitle, In search of the Motherbook, shows it. Indeed, the figure of the narrator-protagonist enacts an extended conception of the self, "interweaving the story of the self with that of parents and family, engaging the $\mathrm{m} /$ other in a dialogue, and speaking for a collectivity underline the fundamentally relational character of identity." (Seyhan 2012, pp. 70-71) Many similarities have been shown between the life-story of the mother and her daughter in Budapest Diary. These similarities have a private, intimate dimension: the author discreetly lets the reader guess that her research into her personal past and her familiar roots started soon after her separation from her husband. She makes a considerable effort throughout her text to understand her parents' love-hate relationship, and she risks "pop-psychoanalytic" interpretations to recognize a structural similarity between her own and her mother's life.

The repressed parental, motherly component of the diarist's self also has its collective dimension, connected to her and her family's origin. "[T]he relationship between her Jewishness and Hungarianness, and the relationship with her mother are interconnected insofar as they both seem instrumental in her 'forgetting' Budapest, in estranging herself from it the way she felt estranged from her mother"as Ksenia Poluektova points out (2009, pp. 445-446). The controversial relation to this repressed Hungarian element of Suleiman's identity is obviously connected to the Holocaust and the persecution of Jewish Hungarians before and during WW II. Belonging to the 1.5 generation of survivors, the author is concerned about a particular version of the postmemory syndrome described by Marianne Hirsch (Hirsch 2008). Postmemory, according to Hirsch, refers to traumatic historical experiences (especially those of the Holocaust) which are not lived personally but transmitted by familial remembrance or by a belonging to a community and which are treated and felt like real, lived traumas. Suleiman only has a few clear memories from the war, but the trauma has become a living experience for her, just like for subsequent generations of survivors' descendants for whom the traumatic past is always present through the loss of family members, and through an extended historical 
consciousness. In addition, her search for familial past and roots coincides with the emergence of a new Holocaust discourse in the eighties, when a worldwide historical conscience as well as new philosophical and historiographical insights established a new politics of remembrance concerning the Shoah. Yet Suleiman's pursuit of traces of her childhood and their parents' former life in Hungary runs into the signs of the tragic disappearance of Hungarian, but also the East-European Jewry. Her quest for documents (birth and marriage certificates) proving the very existence of her family members expresses a real existential anxiety. "She wants tangible evidence of a past that is in danger of being forgotten or erased-a danger that is especially menacing when it comes to documenting the Jewish presence in East-Central Europe," as Szidonia H. Haragos refers to the narrator-protagonist-author's behavior (Haragos 2016). The stories of her two short trips to her parents' birthplaces in the Hungarian and Polish countryside are tinged with a strong melancholy about the disappeared East-Central European Jewish lifestyle, culture, language, religion which once belonged to her ancestors.

The author's ambiguous relationship with her Hungarian roots, a relationship which stems from the country's twentieth-century history becomes even more complicated by the political debates of the newly born democracy in Hungary during her stay in the early nineties. As Poluektova mentions, "Suleiman's idea of 'Hungarian heritage' is irreversibly tainted by the country's history of anti-Semitism and collaboration" (Polouektova 2009, p. 446). In the diary part of her book, the author observes and notes attentively all public and semi-public manifestations of antisemitism in the new-born Hungarian democracy. She comments on far-right wing columnists and political leaders' rhetoric, pondering and refuting their arguments in friendly conversations or in notes for herself. She is passionately interested in Hungarian Jewish people's life, their Jewish identity in the new post-communist era, and also how they had experienced it during the years of communism. She compares Hungarian (East-Central European) and North American Jewish identity and assimilation strategies, and she makes insightful remarks on how the majority of surviving Jewish Hungarians have broken with the traditions and culture of the assimilated but religious Jewish middle-class of the inter-war period. Above all, the political action is an intellectual task for a devoted academic: the topic of tragedies and traumatism in Second World War and their posterior collective working-through and/or repression, the construction of the twentieth-century national past with its oblivion, its blames, and its heroic moments are probably discovered and outlined for Suleiman for the first time in her Budapest Diary, then later developed in her scholarly work, especially in her Crises of Memory and the Second World War (Suleiman 2008) under the general term of policies of remembrance.

\section{Nostalgia, remembering and reconciliation}

Despite the heterogeneous, fragmentary composition of Budapest Diary, and despite the painful nature of the personal as well as collective historical experience expressed in it, Suleiman's book is an attempt to come to terms with the Hungarian elements of her personal and familial past. The book shows the internal process 
of (re)discovering Hungarian culture by the recognition of the aesthetic and intellectual values of one's birthplace. "I felt elated by the beauty of this city. 'It is really a great capital; it can be compared to Paris' I told myself as the cable car rose above the river. [...] Finding the link of beauty is a way to connect Budapest to my life...". (Suleiman 1999, p. 63) The large number of notes and descriptions proves the importance of realizing the literary, artistic, architectural treasures of her native country. Even the birthplace of her mother, an otherwise rather sleepy Hungarian town in the countryside is embellished by this endearing view, and the name of the town (Nyíregyháza) is associated with a modernist Hungarian writer (Gyula Krúdy).

The re-acquisition or re-appropriation of the Hungarian literature and language also seems a part of this operation. Names of streets and public places suddenly become meaningful for Suleiman by discovering Hungarian literary history, and the reacquisition of the language of her first readings makes her praise the logic of the Hungarian spelling: "Hungarian seemed to me the most wonderful, logical tongue in the world. Every consonant, alone or in combination with another, every vowel with or without an accent, has one sound only, no matter where it occurs." (Suleiman 1999, p. 30)

The discovery of the disappeared continent of childhood with its treasures evokes the work of Marcel Proust. The subtitle of Budapest Diary-In Search of the Motherbook-echoes the title of the English translation of his book, but beyond this obvious reference the two works share other similarities. Suleiman's project of recovering the forgotten past is comparable to that of the narrator of the In Search of Lost Time: the story of the remembering guides both protagonists toward a "vita nova," toward the productive "redemption" of becoming a writer. "The experience of seeing again the places of my childhood had restored the sharpness of those images and revealed the desire, long suppressed, to put them into words" (Suleiman 1999, p. 32). However, the diarist refers rather ironically to her vocation $a$ la Proust, especially in the story of her first "nostalgia trip" to Hungary in 1984, when she revisits places of her childhood: "Here was my temps retrouvé at last, only a little the worse for wear." (Suleiman 1999, p. 48) The experience of re-reading the very first book of her childhood-a Hungarian classic of the youth literature genre, The Boys from Pál Street [A Pál utcai fiúk] by Ferenc Molnár-belongs also to this nostalgic search of the lost childhood but the reading could not retrieve the disappeared times neither: "I tried to relive the emotions I had felt as a nineyear-old. It didn't work; no Time Recaptured here." In spite of her efforts, Suleiman expresses here a resistance to the modern idea of nostalgia, to the "desires to obliterate history and turn it into private or collective mythology, to revisit time like space, refusing to surrender to the irreversibility of time that plagues the human condition" as Polouekova quotes from Svetlana Boym's seminal study on nostalgia (Polouektova 2009, pp. 439-440). The failure to recover the past in its emotional plenitude is expressed by the disappointment felt during her pilgrimages to their former home, Acacia street 59, when the repeated visits hardly provided any feeling of homecoming.

The collective, political cause of this missed reunion with the birthplace and the memories of childhood was already shown above. The ambiguous feelings about the returning visit or homecoming are also caused by some private reasons. One of them probably comes from the reduced possibilities to share the experience with others. 
In her nostalgic research of childhood memories and places, Suleiman finds herself between two different generations' expectations: those of her children and of her parents. Although in the story of the 1984 trip to Hungary she describes her two sons as polite and acquiescent, she knows well that for them their Hungarian roots are only something distant and abstract. She soon becomes aware of the fact that she cannot share and transmit her desire to find the wonderland of her childhood to her children. Her boys comment soberly on the differences between the touristic reality of Budapest in the late years of communism and the Budapest remembered by their mother. On the other hand, it seems that Suleiman's (at least first) visit to Budapest becomes a tribute to the memory of her parents. Or, to be more precise, it is not only a question of a tribute to them, but of rendering justice to them, undo symbolically "the wrong committed against them" (Polouektova 2009, p. 433), they who never had the chance to come back. As Polouektova claims, one of the common fantasies of all exiles is the triumphant return home, when, after all, "the return could earn the former persona non grata abundant comfort and popular veneration" (Polouektova 2009 , p. 434). Only, in the case of Suleiman, this desire is transmitted from parents to child. In the true diary section of Budapest Diary she proudly notes an offer to be published in Hungarian translation: "to be a published author in Hungarian! If only my Mother could have lived to see this. Not to mention Daddy!" (Suleiman 1999, p. 149) Behind the self-ironical exclamation one can still notice the child keen to fulfill her parents' desire to be acknowledged in a Hungarian society which doubted their allegiance.

The story of these returns to Budapest is also a voyage into the familial past and its secrets. The thirty-five-year oblivion of the diarist-narrator's Hungarian roots is also explained by her unhappy familial constellation, as it is revealed from the narrative flashbacks scattered evenly across the four parts. They tell the story of a child who grew up amid the love/hate relationship of her parents. The fragmentary childhood stories recall a little girl, alone with her fears, with her concerns about the adult world, who ignores and misunderstands her parents' behavior, their fights during daytime, and their love at night. Reconstructing her own story within the family, Suleiman explains that escaping from this uncomfortable psychological reality of family life and family ties, especially after the premature death of her father, was only possible via a radical rejection of her parents' world, a radical ejection of any serious act of communication with it, and therefore, the rejection of her native Hungarian language: "A year after [the death of her father] I graduated from college and my adult life began. I had forgotten much but had to forget more if I wanted to move ahead. Budapest, childhood, father, all entered the park of discarded memories. I even tried to forget my mother, reducing my contact with her to ritualized visits and conversations where no real communication occurred" (Suleiman 1999, p. 229).

By the very act of its writing, Suleiman's book seeks a reconciliation, to repair the broken relationship with the familial past, with the world of her parents, with their Hungarian past, and with the Hungarian language. Then, the subtitle of the book, "in search of the Motherbook" which is a multilingual pun, playing on the metaphorical meaning of the literal translation of the Hungarian term anyakönyv ("birth certificate" in English) adds a new meaning to the return, because the story of the family bridges an emotional distance, not only a physical or cultural one. 
Again, the double temporal structure of the narration-synchronicity of the time of remembering and the remembered time-allows the author to conduct the analysis of her familial past from a double perspective: that of the little girl ignorant and angry about being neglected, and that of the adult, trying to understand and forgive her parents, but also expressing and acknowledging her own feelings, both in the past, and about the past.

The author's reconciliation with both the collective and private dimension of her past, twentieth-century Hungarian history, and her childhood spent in the shadow of her parents' stormy marriage, is presented as a necessary condition for re-appropriating her birthplace as a home. But this imaginary, intellectual and emotional trip to the past would certainly not be possible without an integration into the present of the city. The daily notes recount the births of new friendships and professional relationships, discoveries of new ideas and intellectual perspectives, and extraordinary cultural experiences. The unique historical moment with the promise of a new beginning in the early nineties in Eastern Europe, together with momentary escape from the routine of her own everyday life, reaches a happy ending in the last pages of the work: "The process of displacement/replacement, which I've thought of as the pattern of my life-each new home displacing the one before it-no longer holds: Budapest doesn't displace or replace any other home but is added to them. When I leave here, the door will not slam shut behind me" (Suleiman 1999, p. 171). As discussed above, the word "home" seems to connote exclusivity, as if exclusivity was necessary to conceive the very notion of home. Suleiman's diary kept during her stay in Hungary and the book resulting from it seek to promote a different conception of home. It is an "additive" conception of home in which different cities, different cultures and languages do not exclude, but complement each other. Budapest Diary shows the process of acquiring that plural concept of home in its stages, "the gradual move over the months here to a feeling of 'at homeness"' (Suleiman 1999, p. 170), the dialectical development which characterizes both the lived experience, and the structure of literary form in which it is told ("this could be the plot of my diary"), which leads from oblivion-via resistance and strangeness-to reconciliation.

Indeed, the words about feeling at home in several places could have been also a conclusion of the book. Suleiman's Budapest Diary relates her personal story of leaving her birthplace with her family as a child, after totalitarian regimes destroyed the life of her parents. Then a new (life) story began, with conscious efforts to leave behind the past - the traumatic history of Eastern European Jewry and the complicated familial ties. Budapest, the Hungarian language, and history as part of the traumatic past were consigned to oblivion. Budapest Diary has a happy ending, because it tells how its hero, Susan R. Suleiman comes to terms with her past, and how she overcomes her resistance to integrating painful elements into her identity. Having a twofold identity, living between two languages and cultures, has its dangers, as the myths of the universal unhomeliness illustrate it, from the figure of wandering Jew to the Flying Dutchman. Suleiman's book tells a different story. It shows that it is possible to have more than one home, that the homogenous, monolithic conception of identity is not the only one which can provide the feeling of being at home. A series of returns, and above all friendships and professional relationships made with locals during her stays in Budapest, as well as the rediscovery of masterpieces of 
Hungarian literature, have transformed the meaning of the city, by reconciling her with the traumatic past, and by making room for a Hungarian element in her identity.

Funding Open access funding provided by University of Pécs.

Open Access This article is licensed under a Creative Commons Attribution 4.0 International License, which permits use, sharing, adaptation, distribution and reproduction in any medium or format, as long as you give appropriate credit to the original author(s) and the source, provide a link to the Creative Commons licence, and indicate if changes were made. The images or other third party material in this article are included in the article's Creative Commons licence, unless indicated otherwise in a credit line to the material. If material is not included in the article's Creative Commons licence and your intended use is not permitted by statutory regulation or exceeds the permitted use, you will need to obtain permission directly from the copyright holder. To view a copy of this licence, visit http://creativecommons.org/licen ses/by/4.0/.

\section{References}

Agulhon, M., \& Nora, P. (Eds.). (1987). Essais d'ego-histoire. Paris: Gallimard.

Apter, E. (1994). Comparative exile: Competing margins in the history of comparative literature. In C. Bernheimer (Ed.), Comparative literature in the age of multiculturalism (pp. 86-96). Boston: John Hopkins University Press.

Haragos, S. H. (2016). "It isn't their language in which I speak their stories": Language, memory, and "unforgetting" in Susan Rubin Suleiman's Budapest Diary: In search of the motherbook and Anca Vlasopolos's No return address: A memoir of displacement. A/B: Auto/Biography Studies, 31(2), 309-332.

Hirsch, M. (2008). The generation of postmemory. Poetics Today, 29(1), 103-128.

Hornung, A. (2013). Return visits: The European background of transcultural life writing. European Journal of Life Writing; Vol 2 (2013): EJLW. Retrieved June 1, 2020, from http://ejlw.eu/article/ view/50.

Luca, I. (2009). Leaves from the motherbook: Susan Suleiman's journey into unforgetting. Prose Studies, 31(3), 267-279. https://doi.org/10.1080/01440350903438211.

Neubauer, J. (2009). Exile: Home of the twentieth century. In J. Neubauer \& B. Z. Török (Eds.), The exile and return of writers from East-Central Europe: A compendium (pp. 4-104). Berlin: Walter de Gruyter.

Neubauer, J., \& Török, B. Z. (Eds.). (2009). The exile and return of writers from East-Central Europe: A compendium. Berlin: Walter de Gruyter.

Nora, P. (2014). 'Introduction' from Essais d'ego-histoire. In V. Castejon, A. Cole, O. Haag, \& K. Hughes (Eds.), S. Muecke (Trans.), Ngapartji Ngapartji. In turn, in turn: Ego-histoire, Europe and indigenous Australia (pp. 21-22). ANU Press. Retrieved July 6, 2020 from www.jstor.org/stable/j. ctt13wwvhn.7.

Polouektova, K. (2009). 'Is there a place like home?' Jewish narratives of exile and homecoming in late twentieth-century East-Central Europe. In J. Neubauer \& B. Z. Török (Eds.), The exile and return of writers from East-Central Europe: A compendium (pp. 432-469). Berlin: Walter de Gruyter.

Seyhan, A. (2012). Writing outside the nation. Princeton: Princeton University Press.

Suleiman, R. S. (1994). Risking who one is: Encounters with contemporary art and literature. Boston: Harvard University Press.

Suleiman, R. S. (1999). Budapest Diary: In search of the motherbook. Lincoln: University of Nebraska Press.

Suleiman, R. S. (2006). Crises of memory and the second World War. Boston: Harvard University Press.

Publisher's Note Springer Nature remains neutral with regard to jurisdictional claims in published maps and institutional affiliations. 